\title{
Trade with China and strategy in South American recent economic development
}

\author{
ERNESTO A. O'CONNOR*
}

Trade between South America and China has been an important source of the high growth shown by those economies in the 2000s. During the globalization of the 1990s, trade between the region and China had not developed so much. A rather sharp growth in China's presence in world trade since the beginning of the 2000s changed the world trade trends for MERCOSUR countries, or, at least, for many of them. The impact of the increasing trade of agrifood has been very relevant, and different per country. Strategy is another important issue, referring to bilateral relations with China. This country should be seen as a partner in the global trade, and not as a new foreign investor for the region, but this may be different in the context of different national strategies of South American countries.

Keywords: economic development; neodevelopment; South America; China; trade; strategy.

JEL Classification: F14; N55; N56; O13; Q17.

\section{INTRODUCTION}

Trade between South America, and MERCOSUR, with China has been, no doubt, an important source of the high growth shown by these economies in the '2000s' ${ }^{1}$. During the globalization of the 1990s, trade between the region and China had not developed so much. The countries had concentrated in the export and import expansion in the context of trade agreements such as Mercosur, the ALCA

\footnotetext{
* Doctor en Economía, Universidad Católica Argentina, Institution: Escuela de Economía Francisco Valsecchi, Facultad de Ciencias Económicas, Universidad Católica Argentina, Buenos Aires, República Argentina, Email: eoconnor@uca.edu.ar. Submitted 4/July/2011; Approved: 7/October/2011.

${ }^{1}$ In this paper, the MERCOSUR countries considered are the six of the Cono Sur: Argentine, Brazil, Paraguay, Uruguay, Bolivia and Chile.
} 
iniciative, European Union, and a growing trade with the countries of the ASEAN area. The intra-area trade and bilateral agreements were the main strategies.

A rather sharp growth in China's presence in world trade since the begining of the new decade in the 2000s changed the world trade trends for MERCOSUR countries, or, at least, for many of them. The tradicional agricultural and food destination of their exports, mainly some countries of Europe and the intra-trade in the continent, was surprised by an increasing demand from China. Agricultural and mineral trade suddenly developed, as Chinese demand of raw materials, food, metals and oil increased.

The Chinese demand has been concentrating in primary goods, such as grains and oilseeds, but also in some industrialized foods, such as meat, dairy, oils, selected fruit and vegetables, fish and moluscs, leather, between other products. Nevertheless, the volumes traded in the two cases have been quite different, with a strong import trend in the first group case. The volume has been, of course, quite strong in the case of oil and metals exports to China, mainly from Brazil and Chile.

The impact of the trade between MERCOSUR countries and China has been different per country, and not necessarily all of them have won with stronger exports from the new paradigm. The bigger or not product export concentration with China, the possibility of export diversification, the introduction of increasing value added goods, and the adoption of long run bilateral trade strategies or not, can be some of the main differences betwenn the relation established by these countries with China.

Long run trends indicate that Latin America and the Caribbean has been the region in the world with the highest growth trade rates with China since 1990 to 2009. In the 2000s, trade with China has increased much more than the world's trade, and even more than any other region of the world, considering exports and imports (ECLAC, 2010). The process increased during the first decade of this century, and in the period 2005-2009 growth rates of China-Latin America and the Caribbean (LAC) trade have doubled the China-world exports and imports. The importance of LAC-China trade has been proved during 2009: the contraction in exports occurred in all destinations except China; while in 2009 exports to the United States and the European Union fell by $26 \%$ and $28 \%$ respectively, those to Asia fell by only $6 \%$, but to China increased by $5 \%$. It is quite important the fact that China's exports to USA have slowed in the last years 2005-2009, showing the lowest growth rate of the chinese exports, to 10.2 annual percent.

These data confirm the growing importance China has acquired as export destination for LATAM. It is important to remenber that the LATAM total trade with China shows structural trend deficit, mainly due to the increasing negative balance of Mexico and Central America. In contrast, the economies of South America, mainly the MERCOSUR ones, show a balance sheet quite balanced trade during the last ten years, that has been relevant to understand their recent high growth.

The paper is organized as follows. The second section presents some trends in natural resources trade between China and MERCOSUR. The third section introduces an example of Chinese impact on development: the MERCOSUR soybean chain trade with China as a development push case. The forth section analyzes some 
market trends for MERCOSUR trade with China, while in the following section the Chinese strategic FDI in MERCOSUR is analyzed. Conclusions summarize some impacts of China's trade on recent and future MERCOSUR economic development.

\section{TRENDS IN NATURAL RESOURCES AND AGRICULTURAL TRADE BETWEEN CHINA AND MERCOSUR}

The trend confirms China as the most dynamic country in the world agrifood goods in the 2000s, and Latin America as the main agricultural net export region of the world. So, new agricultural trade patterns show increasing participation of developing countries, such as China (and other Asian countries such as India) and Latin America, while share of industrialised countries remained stagnated or declined.

LATAM countries trade with China has, of course, heterogeneous characteristics, considered the different products traded and the different countries. There is a big product concentration in the Latin America exports to China, in all the countries of the region. In all country cases, the first five products exported are equivalent to the $80 \%$ or more of the total exports to China. Natural resources exports are nearly the $95 \%$ of all the country cases, including mining, metals and crude oil, with a strong importance over agricultural exports in most of the countries, considering the values and volumes traded. This is the case of Chile, Peru, Bolivia, Ecuador and Venezuela, and also Brazil. In Mexico and Centroamerica, trade with China is mainly concentrated in industrial goods.

Agricultural trade is an increasing component of the trade with China. The importance of Latin America agricultural trade with China is not, in fact, the same for all countries. In particular, considering the seventeen countries of Latin America, some different trade trends can be appreciated between some groups of countries. The MERCOSUR ones have been the most benefied by the Chinese trade boom.

The chinese agrifood demand in the 2000s has been concentrating in primary goods, such as grains and oilseeds. The importance of some industrialized foods, such as meat, dairy, selected fruit and vegetables, fish and moluscs, leather, among other products, has not been high. The volumes traded in the two cases have been quite different, with a strong import trend in the first group case.

Food security has been the most dynamic product, led to the soybean chain exports. For example, MERCOSUR countries, with intensive production of food security goods, such as grains, oils, milk and dairy, meats fresh and meats procesed, have been the most benefit due to the Chinese trade in the 2000s. By far, the main products traded have been the ones of the soybean chain, mainly produced by Brazil and Argentine, and then by Paraguay, Uruguay and Bolivia.

Table I shows the main agricultural products exported to China from the South American countries, in 2001, 2008 and 2009. The trade reference year for this study is 2008 , as 2009 trade volumes have been affected by the international crisis of the subprime mortgages, and the severe drought of 2008 in South America.

In Argentine, for example, $78.7 \%$ of soybeans exports are concentrated in China. 
By the same way, $86 \%$ of meat and edible offal of poltry meat, and $30 \%$ of soybean oil, leather and flour of meat, meat offal and fish are sold to China. Brazil's agricultural exports show a similar path dependence: $66.5 \%$ of soybean and $34 \%$ of soybean oil are exported to China, as the $30 \%$ of the leather traded. Uruguay is another country with high export concentration with China: $89 \%$ of soybeans, $95 \%$ of wools, and $66 \%$ of flour of meat. Chile's agricultural exports are not value important, except flour of meat, meat offal and fish, from which the $52 \%$ are sent to China.

From the China's point of view, the soybean chain is the imports most dependent agrifood chain: $71.5 \%$ of soybean oils come from Argentine and Brazil, and $52 \%$ of soybean from those countries plus Uruguay and Paraguay. South American commodities producers see China as a new market that has been raising export volumes and commodities prices worldwide in the 2000s, and this fact means important income transfers to them. The general perception of the phenomena of increasing food security goods Chinese imports as a structural and permanent fact is the dominat idea in this region. This idea is held by farmers but also by the governments, and the increasing soybean supply in South America, as part of a new international work division, is encouraged as a central strategy. The debate over export concentration vs export diversification is not a relevante item in these South American countries, when in the international trade what you export in fact matters (Hausmann, Hwang and Rodrik, 2007). This may be a dark risk, if the presumtions about China's difficults about the food self-sufficiency are wrong. The current and potential production scale of China can become a destabilizing factor for countries or markets with close links.

Latin America's exports to China of seafood (fresh and processed), fruits and vegetables (fresh and processed) and cut flowers are not so important as food security products. The Andean countries agrifood exports are specialized in these food, but not to China.

By the way, these countries could face global trade competition and China's own exports in the near future in these products. They are especially vulnerable to increases in Chinese supply. Nowadays, Chinese commercial competition is increasing in fish, crustaceans and molluscs, some vegetables and fruits such as asparagus, apples, pears and citrus. Peru, Chile, Colombia, Argentina and Centro American countries exports are threatened by the Chinese production. Chile, for instance, shows no concentration of these products in its trade with China. Nevertheless, Chile's diversified exports of seasonal fruits, grapes, apples, berries, salmon, wine, and forest products may be threatened in the near future by chinese exports and and self-sufficiency. Another risk may be Chinese growing exports of these products to other markets, reducing or eliminating Latin America's market share. For instance, the apples' world market, trade, and China's recent supply is analyzed in the next chapters.

One of the main factors behind the improvment of the external sector of many Latin America economies in the 2000s has been the strength of Chinese demand for commodities, such as oil, metals and food, but this has also had an adverse impact on other Latin American importing countries of these products, that are experiencing increased negative pressures on its balance of payments. 
Total MERCOSUR-China trade includes, between the exports, an important share of crude petroleum oils and metals, such as iron ores and concentrates, ferroalloys, copper ores and concentrates, refined copper and copper alloys, zinc ores and concentrates etc. The most important products in Latin America 's exports to China are minerals and crude petroleum, mainly raw materials. That is the case of Brazil, where iron ores and concentrates are the first export product, with USD 15,051 million (2008), just $50.4 \%$ of total exports to China. Soybean is the second export product in Brazil's example. Chile's copper ores and concentrates, and refined copper exports totalized USD 8,472 million in 2008 , equivalent to $75 \%$ of total exports to China. In the case of Peru, copper, zinc and iron metals have joined USD 3,230 million, just the $719 \%$ of total exports. Venezuela's crude petroleum and oils sum USD 5,781 millio.n, the $88 \%$ of total exports.

In summary, China's rapid increase in world share of agricultural imports and exports during the last ten years has had a relevant impact in the emergence and consolidation of commercial and economic linkages between China and MERCOSUR countries.

\section{MERCOSUR SOYBEAN CHAIN TRADE WITH CHINA AS A DEVELOPMENT PUSH EXAMPLE}

The best example of Chinese impact on production and exports in Latin America is the evolucion of the soybean chain during the 2000s. In the period 1995-2008 , soybean production in the world - considering the seven main producers - recorded a growth rate of $85.1 \%$, increasing from 113 million tonnes in 1995 to 210 million in 2008. This increase has been quite different per regiones. While U.S. production increased $36 \%$, up to 81 million tonnes, China production merely increased $15 \%$, up to 15.5 million tonnes.

The five South America countries registered a growth rate of $177 \%$, with a total production of 114 million tonnes, consolidating as the world's principal soybean production area. Argentine has been, by far, the country with a mayor production expansion, from 12 million tonnes in 1995 to 46 million tonnes in 2008, and 54 million tonnes in 2010, registering the highest rate growth between the main countries (Table II).

The world sown area reached 80,5 million hectares in 2008, from 51,8 million in 2005, but in South America, the change went from 18,9 million to 41,2 million hectares during those eighteen years. So, South America has the first sown area of the world, and their aggregate production has exceeded the U.S.'s one, the world's leading producer. Uruguay $(+5.344 \%)$, Paraguay $(+235 \%)$ and Argentine $(+176 \%)$ are the three countries that show the biggest expansión of soybean production frontier, during that years. USA, with 31 million hectares, leads the ranking, followed by Brazil, 21.7 million, and Argentine, 16.4 million harvested hectares.

The five South American countries lead the soybean world trade market, with USD 11,300 million, followed by U.S. with USD 10,000 million. The trend 1995-2009 shows that U.S. exports have grown from USD 6,000 million to USD 10,000 
million, but South American exports went from USD 1,800 million to USD 11,300 million. This is the proof of the new international division of the cereals and oilseeds production and trade, in which South American countries are soybean suppliers while the rest of the big producers concentrate in wheat and corn, two cereals that are more friendly from the sustainability point of view than soybean is.

South American importance in soybean oil is stronger, with USD 6,5 million exported, as USA exports only USD 730 million. The processing soybean oil industry in Argentine, with USD 4,5 million traded, is the main reason. The trend is also impressive, as South America went fron USD 2,000 million to USD 6,500 million in fifteen years.

There exists a strong concentration of South American soybean complex exports. China's demand explains the soybean phenomenom: $79 \%$ and $48 \%$ of Argentina and Brazil's exports of soybean go to China, as 30\% of both countries soybean oil do. Southamerican soybean is equivalent to the $51 \%$ of chinese demanda (Table III).

\section{Effects on Development of the soybean boom in MERCOSUR countries}

External and internal factors favoured the extraordinary growth of soybean production in South America. The main external factors include the dynamics of the international market for the soybean chain, and important technological innovations from outside the region. China's decision to "sacrifice" soybeans to keep land and water for rice, wheat and corn has been a relevant notice. The adoption of zero-tillage, the use of genetically modified seeds and some changes in production organization, such as the development of a dynamic processing industry, and a favourable public policy framework in South America determined the soybean expansion.

The expansion of soybean production has had important impacts on the economies of South American countries in the 2000s. There are general trends, but, in fact, the emphasis has not been the same for the five countries.

The macroeconomic impact has gone from the tradable sector to the rest of the economy. Soybean expansion has helped improve the general financial and economic performance of the countries, and has been relevant for the external trade surplus, a chronic macroeconomic problem for this region of the world. In fact, these countries had had current account deficit for the last 70 years ought to external macroeconomic and commercial vulnerability, during the Import Industrial Substitution Strategy (1940s-1980s) and during the globalization of the 1990s.

Soybean boom has not only has trade impact. Soybean expansion has effects on other agrifood chain performance, on crop rotation and sustainability, land concentration and small farmers, rural development, and finally, on migration and urban poverty.

The soybean boom has also displaced other crops, such as corn and wheat, and livestock production, to other areas, when possible. From this point of view, the soybean expansion may have not been a net improvement for the global agricultural production of some countries. Soybean has been decisive in the expansion of the agricultural frontier, in particular in Argentina, Brazil and Paraguay.

The hazards of monoculture have confirmed, as instance, less harvested areas of 
corn and wheat in Argentine, since 2008, as in this country economic policies have been favorable to soybean, but not to the other crops and livestock, which have been suffering export restrictions and prohibitions during the last there years. In some areas, sustainability has also been affected by inadequate crop rotation and fertilizer use, as the soybean practise is low-dependent on fertilizers, and the lower plant or wheat and corn - which are more fertilizers demand —, reduces the sustainability.

Argentina and Brazil have also experienced a significant agroindustrial change characterized by the development of a vigorous soybean processing industry and new industries for the food industry for human and animal consumption, the chemical sector, and the energy production of biodiesel (Lazzaroto, J. e M. Hiroshi Hirakuri, 2009).

Transport, storage and port logistics may need a new impulse in the MERCOSUR area, if China's soybean demand continuos growing as in the 2000s. The expansion requires heavy investment in infrastructure in the five countries, even in Argentine and Brazil. It is not clear enough the serach of alternative routes for the export of goods through the Peruvian and Chilean ports on the Pacific.

Another point has been the technological change apllied to agricultural production, related to social changes, as concentration has increased. Changes in the real estate market have been partly fuelled by small producers who have seen no alternative to selling their land, which has intensified rural migration, as in Paraguay. It would be advisable to establish specific policies and social programmes targeting small farmers and the rural poor in areas affected by the expansion of soybean production.

With respect to food security, the food availability is not expected to be threatened by an expansion of soybean production, or an increasing demand from China. Nevertheless, we may remember that this southamerican countries registrer people under the poverty line on the basis of average $30 \%$, urban an rural, including recent poverty increases in Argentina.

The soybean boom is negative related to raising concerns about its own sustainability, and its long-term impact on natural resources, especially forest areas. Deforestation has advanced in some areas of Argentine, Brasil and Paraguay, opening questions about water sustainability in the Southern region of America. The Niña's drought phenomenom has been related to deforestation, but not scientifically tested yet. The agriculturalization trend is expected to continue, mainly as the Chinese soybean demand may be strong for the last five years. So, soybean cultivation will encroach upon rangeland and forests will be cleared for the relocation of stock farming. Some new design of the legal framework for deforestation will be needed, probably with a review of current regulations and a stricter enforcement.

\section{SOME MARKET TRENDS FOR MERCOSUR TRADE WITH CHINA}

China is a dynamic market for Latin American products, but it can soon be a competitor in many products. So, there are risks and opportunities of an incremental dependency of MERCOSUR countries on China trade. Risks arond the growing Chinese market share in some agricultural and seafood global trade sectors, such 
as apples, fish, and another ones in the future. With respect to exports, future elasticity of supply for a few countries is the key. So the export performance question for the future would seem to be a matter of a few countries in a few important products. For example, Chinese soybean and soybean oil demand, and the South American suppy for the next years.

The current situation is characterized by great volatility in the prices of commodities, especially of food products, impulsed by China's and India's demand. If this trend goes on, the aim of food security in Central America will face higher prices for the next years, with current account problems.

An agrifood China concentrated export-led growth strategy, for example around soybean, should have different scenarios in the long run. The intensification and expansion of agriculture in the soybean producing countries of South America will continue in the 2010s, considering the Chinese fixed demand and policies that encourage the use and export of biodiesel, thus providing an additional market for soybean oil. Land availability will not be a major constraint on expected soybean expansion in South American countries, but the main point is the impact of increased soybean seeded area on the dynamics of land use, in particular on deforestation and unsustainable use of ecologically fragile land, especially in Argentine, where soybean has displaced planting of corn and wheat, due to public policies disincentives. The soybean single crop has resulted in insufficient rotation for the conservation of soil fertility and quality.

South American countries soybean strategy may be threatend by the National Plan for Expansion of Grain Production Capacity (NPEGC) aimed by the China's goverment since 2009 (NDRCCG, 2009). China continues promoting structural reforms in the agricultural sector, aimed to increase productivity in agriculture and improving the food security. The plan refers to an expansion plan for grain production, with the aim of covering $95 \%$ of domestic needs by 2020 , and eliminate dependence on external supply. China's grain production has averaged above 500 million metric tons (MT, or 500 billion kilograms) annually from 2007-2009, feeding a population of more than 1.3 billion tops the Government of China's agenda. To meet the near self-sufficiency goal in grain production over the coming years, China's production must increase to meet the demands of its growing population and consumption. The Government wants to increase grain acreage and raise yields. According to the plan, grain yields must increase by $0.9 \%$ annually to meet the target of an increase of 50 million MT in production capacity, and a total aim of 550 million tonnes in 2020 .

China is now self-sufficient in grains like rice, corn and wheat. With relation to soybeans, of a total 51.4 million tonnes consumed in 2008, 41.1 million were imported. The NPEGC includes a soybean expansion strategy with the incorporation of cutting-edge technology, to improve output and productivity. South American countries that are net exporters of soybean and oil should take this into account, especially Argentine, which has high concentration in soybean chain exports to China, and has developed a concentration in the crop production around soya, against another crops such as corn and wheat. Chinese imports restrictions 
on argentine soybean oil during some months of 2009 is a recent example of these risks. The Chinese soybean chain plan should include in a first step low soybeans oil imports, and increasing soybean imports, to industrialize more grain in their own soya processing industry.

Another trend to consider is referred to the exporting potencial of Chinese agrifood and seafood. Fish, molluscs and crustaceans are the strongest products in Chinese exports, and may threaten Chilean exports. Vegetables, meat, fruits (apples and pears), and sugar are other products with a favorable export potential.

Another point is related to some determinants of the LATAM global trade, such as policies or infrastructure. Policies are important because global trade is not a chance result, but a deliberated export long-run strategy. LATAM countries in the APEC, such as Mexico, Chile and Peru may have some benefits, mainly Chile and Peru, with the Chinese bilateral relation in the next years. Argentine, for instance, should eliminate export quantitative restrictions and taxes to improve much more in global trade.

Sectoral performance will have a stable trend unless some countries apply certain corrective policies. For instance, Argentine and Brazil need better port infrastructure if the soybean phenomena grows up, pulled by China and India. China may have an important role in FDI infrastructure.

Road transport prices and efficiency in LATAM are a major issue, and agricultural products being largely carried by road, may impulse a review of the market structure of road transport. So, in a few main exporting countries a new transport strategy, aroun the rail, would seem advisable to assess the transport market effectiveness.

\section{TOWARDS A STRATEGIC CHINA'S FDI IN MERCOSUR?}

Latin America is an important destination of China FDI, though its weight in the total China FDI is still lower. In 2009, China FDI to LATAM totalized a stock of USD 41.179 million. By destination, in 2009, it is estimated that about $17 \%$ of China's non-financial FDI abroad has led to economies of Latin America and the Caribbean. However, over $95 \%$ of this wealth is concentrated in two economies, the Cayman Islands and British Virgin Islands (ECLAC, 2010).

There is a strong trend towards concentration in natural resources, but also an increasing diversification into manufacturing and services. Brazil and Peru are the main destinations, with one third of the stock, and more than half of total flows of China FDI to Latin America. Argentina is the third largest destination of Chinese FDI in the region (IDB-INTAL, 2010).

China's FDI policy in the 2000s has focused on diversification, access to raw materials, such as metals, and energy, seeking the assurance of natural resources and the consolidation of transnational networks of production.

China is not yet a major player in global FDI, but it is the second source of direct investment in the emerging world. Until now, Chinese FDI has not implied a crowding-out private investments, as the Chinese objective is concentrated in a few areas, and is part of a global concentration process started in the 1990s. 
Lately, a growing growing number of Chinese public corporations operating in the sectors of natural resources and re-manufacturing has invested in the region, but the amount and scope of the activities of these firms are still fairly limited.

The main countries were the Chinese FDI has directed are Peru, Argentina, Brasil and Chile. In Peru, Chinese companies have invested mainly in mining operations. More than USD 1.1 billion have been invested in the mining sector with the arrival of companies like Aluminium Corporation of China (Chinalco) and Minmetals/Jiangxi Copper. Chinese companies have invested nearly USD 1,500 million in the Andean country, mainly in the mining sector. Chinese mining companies have plans for another USD 4.5 million in investments in their Peruvian operations. Peru is currently the world's second biggest copper producer, behind Chile. Mining exports are crucial for Peru, with USD 16 billion, comprising about $60 \%$ of the country's total export value in 2009. A free trade agreement between Peru and China went into effect in March 2010, and the government said it could lead to increases in trade and investments.

A recent agreement between China and Brazil will support the company Petrobras in oil exploration in the Atlantic, for U.S. \$ 10,000 million over the next five years. The Brazilian company EBX and Wisco China will build a steel complex in Rio de Janeiro, which will require an investment of USD 5,000 million. In Rio de Janeiro, Wuhan Iron and Steel, the third steelmaker of China, will build a newplant. In Brazil, five brands of Chinese cars can be acquired: Chery, Chana, Effa, Jinbei and Hafei, and more investments are expected.

In Argentine, MCC Minera Sierra Grande, in the province of Río Negro, property of the Chinese Corporation MCC, is exporting iron to China since the end of 2010. China Petrochemical Corporation, Sinopec, the biggest public chinese oil firm and the first of Asia, has bought the american firm Oxy, and Cnooc has bought Pan American Energy by the end of 2010. Sinopec has also acquired some Repsol oil fields.

The state-owned China State Farms Heilongjiang Beidahuang Business Trade Group has pledged investments in irrigation to 300,000 hectares in the province of Río Negro, Argentina, and will receive in return the exclusive sale of agricultural production obtained. In addition, Beidahuang will invest in the port of San Antonio Este.

One question related to the effects of Chinese FDI in Latin America concerns the purchase or rent of land, as the previous example someway shows. The debate between land property and sovereignty may appear in MERCOSUR and LATAM countries in the near future.

\section{THE IMPORTANCE OF THE NATIONAL STRATEGY ON SUSTAINABLE DEVELOPMENT: NEO DEVELOPMENT AND OTHER STRATEGIES}

Trade may be a consequence of international flows, or trade may be a mixed result of good luck and a national strategy. Rodrik (2011) has made a strong defense of the idea of a strong State, with a long run strategy, in the context of "the trilemma" among National States, Democracy and Globalization. 
In this context, some countries of the region have established trade and economic relations with China, and with the rest of the world, since a long run national strategy. Brazil is the main example. The neodevelopment strategy - in the idea of Bresser Pereira (2007) — started in the end of the 1990s and continued during the last decade of the 2000s, placing this country as a global agrifood leader, in the context of a radical change in the international division of trade. Chile and Peru are members of the APEC, and have settled their trade to the Pacific area. Argentine, in our own view, decided not to take advantage of the global context, and has increasingly restricted exports and imports, losing the opportunity of a neodevelopment (O'Connor, 2010). In the Helpman (2008) point of view, when trade has not improved inequality inside the countries, the asian opportunities have in fact improved social situation in some South American countries, such as Brazil, Chile or Peru.

Some lessons may be learnt, in order to develop some suggestions to the national development actors of South American countries. It is important to assess the challenges and opportunities for sustainable growth and poverty reduction in these countries, as result of expansion of trade with China.

Some scenarios for next decades include the evolution of the global mortgage crisis, global macroeconomic imbalances, currency wars, and of course, local policy in China, and even a new international work division. The possible effects over China's medium run growth and agrifood and seafood MERCOSUR exports to China are not clear, as opportunities and risks exist. An optimistic vision emphasizes the emerging markets oportunities for MERCOSUR exports, as population in all emerging countries will demand more food. In the Fogel (2009) point of view, the Asian and China's miracle is changing and is going to change much more the dynamics of the economics development and the sources of growth, such as technological change, global economic balance, some endogenous growth models aspects, and the impact of institutions on development. MERCOSUR countries may be very influenced by the Asian and Chinese future politics.

An export - led growth strategy may be the first point - and an important element of the Neodevelopment strategy - , as the increasing trade between MERCOSUR and China in the 2000s has been a mere consecuence of the sudden Chinese demand, and not an endogenous process for most of the countries. This strategy should take into account export diversification, not just raw materiales and some foods, as what you export is relevant for development (Hausmann, R, J.Hwang and D. Rodrik, 2007).

Public policies may be intelligent and long-run strategic, optimizing trade results and promoting tradable activities. Natural resources production may be one of the main objectives, as the probability of China's self-sufficiency does not look certain.

A public framework favourable to property rights and new technology change is a necessary condition, for best practices. Improving rural infrastructure for domestic transport and export is another aim, in which China may be an important partner.

Soybean boom has not only has trade impact, but undesirable ones. Soybean expansion has effects on crop rotation and sustainability, land concentration and small farmers, rural development, and finally, on migration and urban poverty. These changes embrace problems that national policies should take into account. 
Soybean has been no neutral to rural development. It has also driven farm land concentration and enlargement, generating problems to small producers who have seen no alternative to selling their land, which has intensified rural migration, especially in Paraguay. It would be advisable to establish specific policies and social programmes targeting small farmers and the rural poor in areas affected by the expansion of soybean. The soybean boom is also negative related to raising concerns about its own sustainability, and its long-term impact on natural resources, especially forest areas. Policies should also consider these aspects in a long-run strategy.

Different and new partnerships between MERCOSUR countries and China should be explored, as China's FDI is interested in LATAM natural resources. Market integration and more trade with China exporting value added agricultural products should be one of the aims of the countries of the region. The potential seafood Chinese competition should be part of other countries agreement with China.

National development of South American countries may be, then, the result of a national globalization strategy, considering China as a partner, not just a mere global buyer of the abundant natural resources of this region of the world.

\section{REFERENCES}

BRESSER-PEREIRA, Luiz Carlos (2007). "Novo desenvolvimento e ortodoxia convencional”, in Globalização, Estado e desenvolvimento - Dilemas do Brasil no novo milênio. Fundação Getulio Vargas.

ECLAC (2010). La República Popular de China y América Latina y el Caribe: hacia una relación estratégica. Santiago, Chile. Abril.

FOGEL, Robert (2009). "The impact of the Asian miracle on the theory of economic growth", NBER Working Paper 14967.

HAUSMANN, Ricardo, Jason HWANG and Dani RODRIK (2007). "What you export matters," Journal of Economic Growth, Spring, vol. 12(1), pages 1-25, March.

HELPMAN, Elhanan, Oleg ITSKHOKI and Stephen REDDING (2008). "Inequality and unemployment in a global economy", NBER working paper series. Working Paper 14478

IDB-INTAL Institute for the Integration of Latin America and the Caribbean. Nuevas tendencias en las políticas comerciales y productivas de la República Popular China (2010). Carta mensual INTAL 166. Junio.

International Trade Centre. Trade Statistics. www.intracen.org.

LAZZAROTO, Joelsio José e Marcelo Hiroshi HIRAKURI (2009). "Evolução e perspectivas de desempenho econômico associadas com a produção de soja nos contextos mundial e brasileiro". Documentos 319. EMBRAPA-SOJA. Ministério da Agricultura, Pecuária e Abastecimento. Londrina PR, Brasil. Dezembro.

National Development and Reform Commission of the China Government, NDRCCG (2009). "National Plan for Expansion of Grain Production Capacity by 50 billion kilograms (50 million MT) during 2009-2020.” November. Beijing, China.

O'CONNOR, Ernesto A. (2010). "El Neodesarrollismo brasileño como propuesta de desarrollo para Argentina” Economic Studies of International Development. Vol. 10-2 Julio-Diciembre 2010. Universidad de Santiago de Compostela. Galicia. España. http://www.usc.es/ economet/eedi.htm OECD-FAO (2010). Agricultural Outlook 2010-2019.

RODRIK, Dani (2011) The Globalization Paradox: Democracy and the Future of the World Economy. W. W. Norton \& Company. Februar, 2011.

USDA- United States Agriculture Department (2010). USDA Agricultural Projections to 2019, USDA, Office of the Chief Economist. February. 


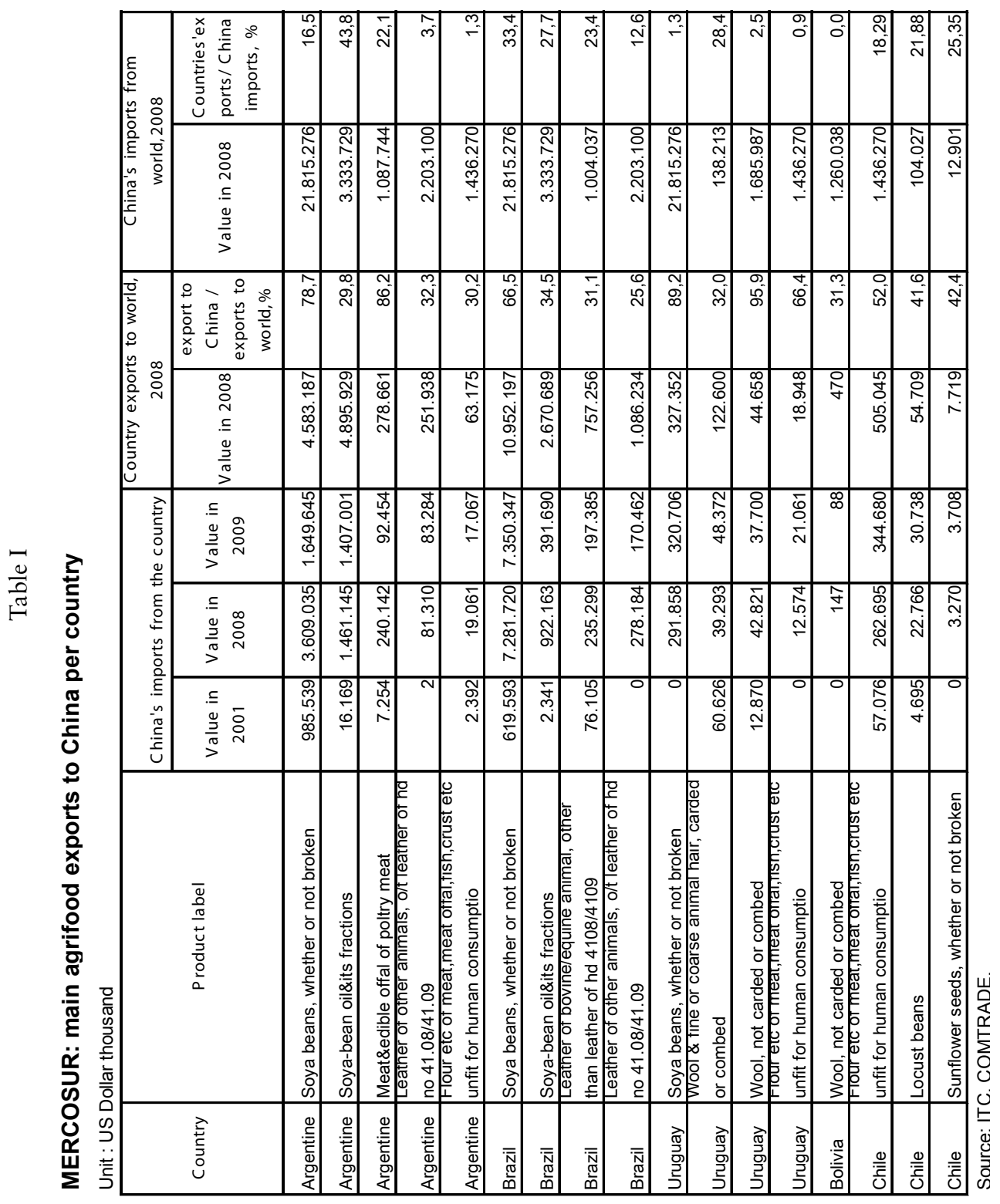


Table II

Soybeans, production by countries, MERCOSUR and U.S. (1995-2008) in tonnes

\begin{tabular}{|l|r|r|r|}
\hline & \multicolumn{1}{|c|}{1995} & \multicolumn{1}{c|}{2008} & var \% 2008/1995 \\
\hline Argentina & 12.133 .000 & 46.238 .087 & 281,1 \\
\hline Bolivia & 870.074 & 1.259 .676 & 44,8 \\
\hline Brazil & 25.682 .636 & 59.242 .480 & 130,7 \\
\hline China & 13.510 .894 & 15.545 .141 & 15,1 \\
\hline Paraguay & 2.212 .109 & 6.311 .794 & 185,3 \\
\hline United States of America & 59.174 .000 & 80.748 .700 & 36,5 \\
\hline Uruguay & 15.500 & 880.000 & 5577,4 \\
\hline South America (Total) & 41.103 .373 & 114.103 .573 & 177,6 \\
\hline Total & 113.598 .213 & 210.225 .878 & 85,1 \\
\hline
\end{tabular}

Source: FAOSTAT

Table III

\section{Soybeans and soybean oil: MERCOSUR exports to China (2008)}

Unit : US Dollar Thousand

\begin{tabular}{|l|r|r|r|}
\hline Country & \multicolumn{1}{|c|}{$\begin{array}{c}\text { Exports to } \\
\text { world }\end{array}$} & \multicolumn{1}{c|}{$\begin{array}{c}\text { Exports to } \\
\text { China }\end{array}$} & $\begin{array}{c}\text { Export to } \\
\text { China / Total } \\
\text { Exports }\end{array}$ \\
\hline Argentine. Soyabeans & $4.583 .262,9$ & $3.609 .035,2$ & 78,7 \\
\hline Argentine. Soyabean oil & $4.895 .928,9$ & $1.461 .145,5$ & 29,8 \\
\hline Brazil. Soyabeans & $10.952 .196,5$ & $5.324 .052,2$ & 48,6 \\
\hline Brazil. Soyabean oil & $2.670 .689,3$ & $829.875,7$ & 31,1 \\
\hline Paraguay. Soybeans & $1.485 .311,7$ & & 16,9 \\
\hline Paraguay. Soybean oil & $488.664,7$ & $82.589,2$ & 11,2 \\
\hline Uruguay. Soybean & $455.773,0$ & $50.869,5$ & - \\
\hline Bolivia. Soybean & $36.771,1$ & & 51,3 \\
\hline Bolivia. Soybean oil & $172.389,9$ & & \\
\hline $\begin{array}{l}\text { Argentina-Brazil-Paraguay- } \\
\text { Uruquay-Bolivia. Soyabean }\end{array}$ & $17.513 .315,3$ & $8.983 .956,9$ & \\
\hline
\end{tabular}

Source: ITC - COMTRADE 